\title{
Mitogenomics, Phylogeny and Morphology Reveal Ophiocordyceps pingbianensis Sp. Nov., an Entomopathogenic Fungus from China
}

\author{
Siqi Chen ${ }^{1,2,+}$, Yuanbing Wang ${ }^{1,2,+}$, Kongfu Zhu ${ }^{1,2}$ and Hong Yu ${ }^{1,2, *}$ \\ 1 Yunnan Herbal Laboratory, College of Ecology and Environmental Science, Yunnan University, \\ Kunming 650091, China; csq2017@mail.ynu.edu.cn (S.C.); wangyb001@126.com (Y.W.); \\ zkf@mail.ynu.edu.cn (K.Z.) \\ 2 The International Joint Research Center for Sustainable Utilization of Cordyceps Bioresources in China and \\ Southeast Asia, Yunnan University, Kunming 650504, China \\ * Correspondence: hongyu@ynu.edu.cn \\ + These authors contributed equally to this work.
}

Citation: Chen, S.; Wang, Y.; Zhu, K.; $\mathrm{Yu}, \mathrm{H}$. Mitogenomics, Phylogeny and Morphology Reveal Ophiocordyceps pingbianensis Sp. Nov., an Entomopathogenic Fungus from China. Life 2021, 11, 686. https:// doi.org/10.3390/life11070686

Academic Editors: Armin Mešić and Ivana Kušan

Received: 15 June 2021

Accepted: 9 July 2021

Published: 14 July 2021

Publisher's Note: MDPI stays neutral with regard to jurisdictional claims in published maps and institutional affiliations.

Copyright: (c) 2021 by the authors. Licensee MDPI, Basel, Switzerland. This article is an open access article distributed under the terms and conditions of the Creative Commons Attribution (CC BY) license (https:// creativecommons.org/licenses/by/ $4.0 /)$.

\begin{abstract}
The new entomopathogenic fungus Ophiocordyceps pingbianensis, collected from Southeast China, was described by mitogenomic, morphological, and phylogenetic evidence. The systematic position of $O$. pingbianensis was determined by phylogenetic analyses based on six nuclear gene (ITS, tef1- $\alpha, n r S S U, n r L S U, r p b 1$ and $r p b 2)$ and 14 mitochondrial protein-coding gene (PCGs) (cox1, cox2, cox3, atp6, atp8, atp9, cob, nad1, nad2, nad3, nad4, nad5, nad6 and nad4L) data. Phylogenetic analyses reveal that $O$. pingbianensis was belonged to the Hirsutella nodulosa clade in the genus Ophiocordyceps of Ophiocordycipiaceae. This fungus exhibits distinctive characteristics which differed from other related Ophiocordyceps species with slender and geminate stromata, monophialidic conidiogenous cells with an inflated awl-shaped base, a twisty and warty phialide neck and a fusiform or oval conidia, as well as being found on a tiger beetle of Coleoptera buried in moss at the cave. The complete mitochondrial genome of $O$. pingbianensis was a circular DNA molecule 80,359 bp in length, containing 15 PCGs, 24 open reading frames genes (ORFs), 25 transfer RNA genes (tRNAs) and 27 introns. Ophiocordyceps pingbianensis, containing 27 introns, has the second largest mitogenome in Ophiocordycipiaceae and was next to O. sinensis. To our knowledge, this is the first report of the mitogenome from a new entomopathogenic fungus, and thus provides an important foundation for future studies on taxonomy, genetics and evolutionary biology of Ophiocordycipiaceae.
\end{abstract}

Keywords: mitochondrial genome; new species; phylogenetic analyses; taxonomy

\section{Introduction}

Ophiocordyceps Petch was belonged to Ophiocordycipitaceae of Hypocreales [1], erected initially by Petch in 1924. In 1931, Petch defined O. blattae Petch as a type species [2]. In this genus, the most famous species O. sinensis ((Berk.) G.H. Sung, J.M. Sung, Hywel-Jones and Spatafora) is mainly distributed in the high altitudes of the Qinghai-Tibet Plateau [3]. Given the morphological characteristics of asci from several species lacking pronounced apical hemispheric caps and ascospores without being disarticulated into part-spores, Ophiocordyceps acts as a subgenus of Cordyceps Fr. sensu lato [4-6]. Subsequently, the family Ophiocordycipitaceae was established by the type genus Ophiocordyceps [1]. Over the last few years, more than 270 species of Ophiocordyceps have been described, making it the largest genus in Ophiocordycipitaceae [1,7-13]. Ophiocordyceps is characterized by a darkly pigmented and tough, wiry, fibrous or pliant stromata ordinarily or obliquely arranged superficial to immersed perithecia; ascospores are commonly cylindrical and multi-septate, disarticulated into part-spores or non-disarticulating [1,14,15].

Asexual morphs of Ophiocordyceps consist of Hirsutella Pat., Hymenostilbe Petch, Paraisaria Samson and B.L. Brady, Sorosporella Sorokin, Stilbella Lindau, as well as Syngliocladium 
Petch $[1,14]$. The main anamorph of Ophiocordyceps refers to Hirsutella. The fungal genus Hirsutella was a pathogen of insects, mites and nematodes, which was erected by Patouillard in 1892, and Hirsutella was initially described by Petch in 1924. In 1998, Hodge introduced the monograph and molecular phylogeny of Hirsutella. To be specific, she reviewed the taxonomy of Hirsutella species and described 68 species to pertain to Hirsutella [16]. Hirsutella was considered to show relationships to the genus Ophiocordyceps typified by a sexual morph [1]. The morphological characteristics of this genus was considered to produce basally inflated phialides, tapering towards the apex, discontinuous hymenial layer and conidia embedded in a mucous sheath $[15,17,18]$.

The mitochondrion acts as a master regulator of metabolism. As DNA sequencing technology leaps forward, the mitochondrial DNA (mtDNA) is recognized as an effective marker for phylogenetic analysis, with the advantage of exhibiting a faster mutation rate than nuclear DNA [19]. Moreover, mtDNA is also appropriate for phylogenetic analysis due to its high copy number and conservative gene functions [20].

Furthermore, there are differences in the size of fungal mitochondria in different species. From the current reports, the smallest mitogenome known in the fungi was $12.1 \mathrm{~kb}$ in Rozella allomycetis (Doweld) Letcher in Cryptomycota [21], while the largest was 272,238 bp in Morchella importuna M. Kuo, O'Donnell and T.J. Volk in Pezizomycetes [22]. The mitochondrial genome of the Ophiocordycipitaceae species is like an obvious closed circular structure, comprising naked double stranded DNA. It commonly contains 15 protein-coding genes (e.g., 3 subunits of cytochrome c oxidase (cox1-3), 3 subunits of ATP synthase (atp6, 8 and 9), cytochrome b gene (cob), 7 subunits of NADH dehydrogenase (nad1-6, nad4L) and 1 ribosomal protein S3 (rps3), as well as ribosomal RNA genes ( $r n l$, $r n s)$ and transfer RNA genes ( $t r n)$. Thus far, mitogenomes of only ten species in Ophiocordycipitaceae have been described, in which mitogenomes of Hirsutella species have been rarely reported. The existing sequence data of mitogenome from NCBI only include H. minnesotensis Sen Y. Chen, Xing Z. Liu ad F.J. Chen, H. rhossiliensis Minter and B.L. Brady, H. thompsonii F.E. Fisher and H. vermicola M.C. Xiang and Xing Z. Liu. The largest mitogenome known reached $157.5 \mathrm{~kb}$ in O. sinensis [23], and the smallest was 52,245 bp in H. minnesotensis [24]. Different variations of mitogenome sizes of hypocrealean fungi were largely attributed to differences in the number/length of introns and the length of intergenic regions, and the mentioned introns most likely were obtained through horizontal transfer from other fungal species [25].

In the present study, an unknown species of Ophiocordyeps attacking a larva of tiger beetle was collected from Daweishan National Nature Reserve, Pingbian County, Yunnan Province, China. Mitogenomics, phylogeny and morphology of this fungus were determined, and its systematic position was established in Ophiocordycipitaceae, It was revealed a new species of Ophiocordyceps with a Hirsutella morph. The complete mitogenome of the new fungus was sequenced, assembled and annotated. Genome structures, gene contents, codon usage and gene arrangement were analyzed.

\section{Materials and Methods}

\subsection{Fungal Materials and Isolation}

In this study, live specimens were collected on a tiger beetle of Coleoptera buried in the moss in a cave in Daweishan National Nature Reserve, Pingbian County, Yunnan Province, China. Before examination, the specimen was transferred to a laboratory and then stored at $4{ }^{\circ} \mathrm{C}$. To detect and further study the culture, stromata were photographed and then measured with an Olympus SZ61 stereomicroscope. A stroma of the fungus growing from the beetle larva fell to small segments nearly $5 \mathrm{~mm}$ long. The respective segment was surface-sterilized in $30 \% \mathrm{H}_{2} \mathrm{O}_{2}$ for $5 \mathrm{~min}$, then soaked in $70 \%$ alcohol for $2 \mathrm{~min}$ and subsequently rinsed sufficiently in sterilized water, and lastly dried on the sterilized filter paper. Afterwards, the segments were placed on Potato Dextrose Agar (PDA) plates. The specimen was deposited in Yunnan Herbal Herbarium (YHH), Yunnan University. 
The cultures of this fungus were deposited in Yunnan Fungal Culture Collection (YFCC), Yunnan University.

\subsection{Morphological Observations}

The fresh specimen, including stromata and host, were photographed with Olympus CX40 and BX53 microscopes. The colonies on PDA plates were cultured at $4{ }^{\circ} \mathrm{C}$ for 4 weeks, and the colonies characteristics (size, texture and color) were photographed with the Cannon 700D camera to characterize the morphology of colonies. For to asexual morphological descriptions, microscope slide cultures were prepared by placing a small amount of mycelia on 5-mm diameter PDA medium blocks that were overlaid by a cover slip. The cultures on the slants were transferred to PDA plates and then cultured with an incubator for $25 \mathrm{~d}$ at $4{ }^{\circ} \mathrm{C}$. Next, the colonies were photographed and then measured every four days. The micro-morphological observations and measurements were performed under Olympus CX40 and BX53 microscopes, as well as a FEI QUANTA200 scanning electron microscope [26].

\subsection{DNA Extraction, PCR and Sequencing of Nuclear Genes}

Axenic living cultures of the new species were collected from a PDA plate to prepare for DNA extraction. The DNA extraction was performed with the CTAB method in Liu et al. [27]. The nuclear ribosomal small subunit $(n r S S U)$ was amplified with the primer pair nrSSU-CoF and nrSSU-CoR [28]. The nuclear ribosomal large subunit ( $n r L S U$ ) and translation elongation factor $1 \alpha(t e f-1 \alpha)$ were amplified with the primers LR5 and LR0R $[29,30]$ and EF1 $\alpha$-EF and EF1 $\alpha$-ER [1,30], respectively. To amplify the largest subunits of RNA polymerase II $(r p b 1)$ ( $r p b 2)$, the primer pair RPB1 $-5^{\prime} \mathrm{F}$ and RPB1- $5^{\prime} \mathrm{R}$, as well as the primer pair RPB2 $-5^{\prime} \mathrm{F}$ and $\mathrm{RPB} 2-5^{\prime} \mathrm{R}$, were applied respectively [31]. The nuclear ribosomal internal transcribed spacer region (ITS) was amplified using the primer pair ITS4 and ITS5 [32]. The polymerase chain reaction (PCR) assay was performed as described by Wang et al. [33]. PCR products were sequenced with an automatic sequence analyzer (BGI). When PCR products could not be sequenced directly, cloning was performed with the TaKaRa PMD ${ }^{\mathrm{TM}} 18-\mathrm{T}$ vector system (TaKaRa Biotechnology, Dalian, China).

\subsection{Sequencing, Assembly and Annotation of Mitogenome}

After the DNA extraction and the quality detection, the extracted genomic DNA was transported on dry ice for high-throughput sequencing at Novogene Co., Ltd. (Beijing, China) by applying dry ice for high-throughput sequencing. Following standard procedures, the extracted genomic DNA was sequenced on the Illumina HiSeq 3000 platform using a 350 bp paired-end reads, which resulted in 3 GB of data and $100 \times$ sequencing depth. Using the high-throughput sequencing data, mitogenome of the new species was assembled with the software SPAdes v. 3.11 .0 [34], which involved three processes, i.e., (1) initial splicing, (2) contig screening and extension and (3) hole filling and re-splicing. The complete mitogenome of the new species was annotated by combining the results of a MFannot tool [35] and an ARWEN web server, with artificial correction. The content of the annotated sample mainly included the protein coding genes (PCGs), the rRNA genes, the tRNA genes and the open reading frames (ORFs). Next, the graphical map of the complete mitogenome of the new species was generated with the software Organellar Genome DRAW tool [36].

\subsection{Sequence Analyses of Mitogenome}

The GC content of the mitochondrion sequence was analyzed using Mega 7. tRNA genes were analyzed with tRNAscan-SE 2.0 (http://lowelab.ucsc.edu/tRNAscan-SE/ index.html, accessed on 1 October 2020). Sequence Manipulation Suite (http:/ /www. detaibio.com/sms2/codon_usage.html, accessed on 20 October 2020) and CodonW 1.4.4 were adopted to calculate codon usage in the mitogenome. Genomic synteny analysis of six Ophiocoryceps species was conducted using Mauve v2.4.0 (A.C. Darling, 2004). 


\subsection{Phylogenetic Analyses}

Raw trace files were inspected and edited using MEGA7. Two species of Tolypocladium inflatum W. Gams and T. ophioglossoides J.F. Gmel were designated as the outgroup to root the trees. Five gene ( $n r S S U, n r L S U$, tef-1 $\alpha, r p b 1$ and $r p b 2)$ sequences of Hirsutella, Ophiocordyceps and the outgroup, were retrieved from GenBank. The majority of ITS sequences of Hirsutella were also retrieved from GenBank. Some manual adjustments were made as the nrSSU gene contained an intron (Table S1). The sequences were aligned with the programmes Clustal X2.0 and MEGA7 [37,38]. Phylogenetic analyses were performed by combining the concatenated 14 PCGs sequences generated here with other mitogenomic sequences of species in Hypocreales downloaded from NCBI. Neurospora crassa Shear and B.O. Dodge and Podospora anserine Rabenh were designated as the outgroup. The 14 mitochondrial PCGs were aligned using MUSCLE. [39]. Maximum likelihood (ML) and Bayesian Inference (BI) phylogenetic trees were estimated using RaxML 7.0.3 and MrBayes v.3.1.2. $[26,40,41]$.

\section{Results}

\subsection{Phylogenetic Analyses Based on Nuclear Genes}

For the ML and BI trees estimated for the five nuclear genes, the new species was closely related to H. liboensis X. Zou, A.Y. Liu and Z.Q. Liang and O. cochlidiicola (Kobayasi) G.H. Sung, J.M. Sung, Hywel-Jones and Spatafora, clustered as a separate clade from other allied species in the genus Ophiocordyceps (Figure 1). For the ML and BI trees estimated for the ITS sequences, there was no significant different in topology between the five-gene and ITS phylogenetic trees. The new species formed an independent clade from its allied species of Hirsutella and was closely grouped with H. liboensis and O. cochlidiicola (Figure 2). 


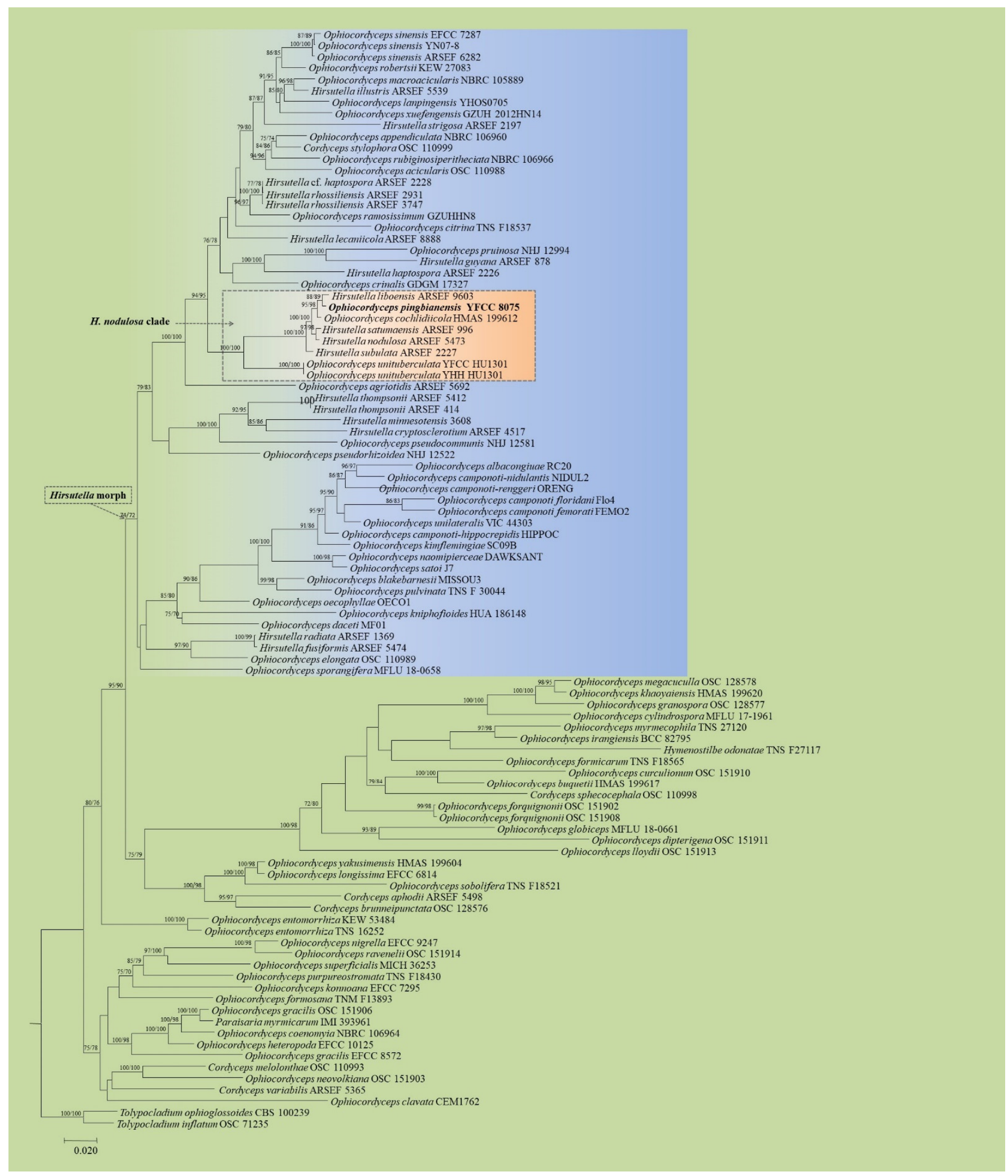

Figure 1. Phylogenetic tree of Ophiocordyceps inferred from Maximum Likelihood (ML) and Bayesian Inference (BI) analyses based on a five-gene $(n r S S U, n r L S U, t e f-1 \alpha, r p b 1$ and $r p b 2)$ dataset. Values at the nodes before and after the backslash are ML bootstrap proportions and BI posterior probabilities, respectively. Support values greater than $50 \%$ are indicated at the nodes. Phylogenetic tree shows the placement of O. pingbianensis within the genus Ophiocordyceps. Tolypocladium inflatum and T. ophioglossoides are designed as the outgroup. 


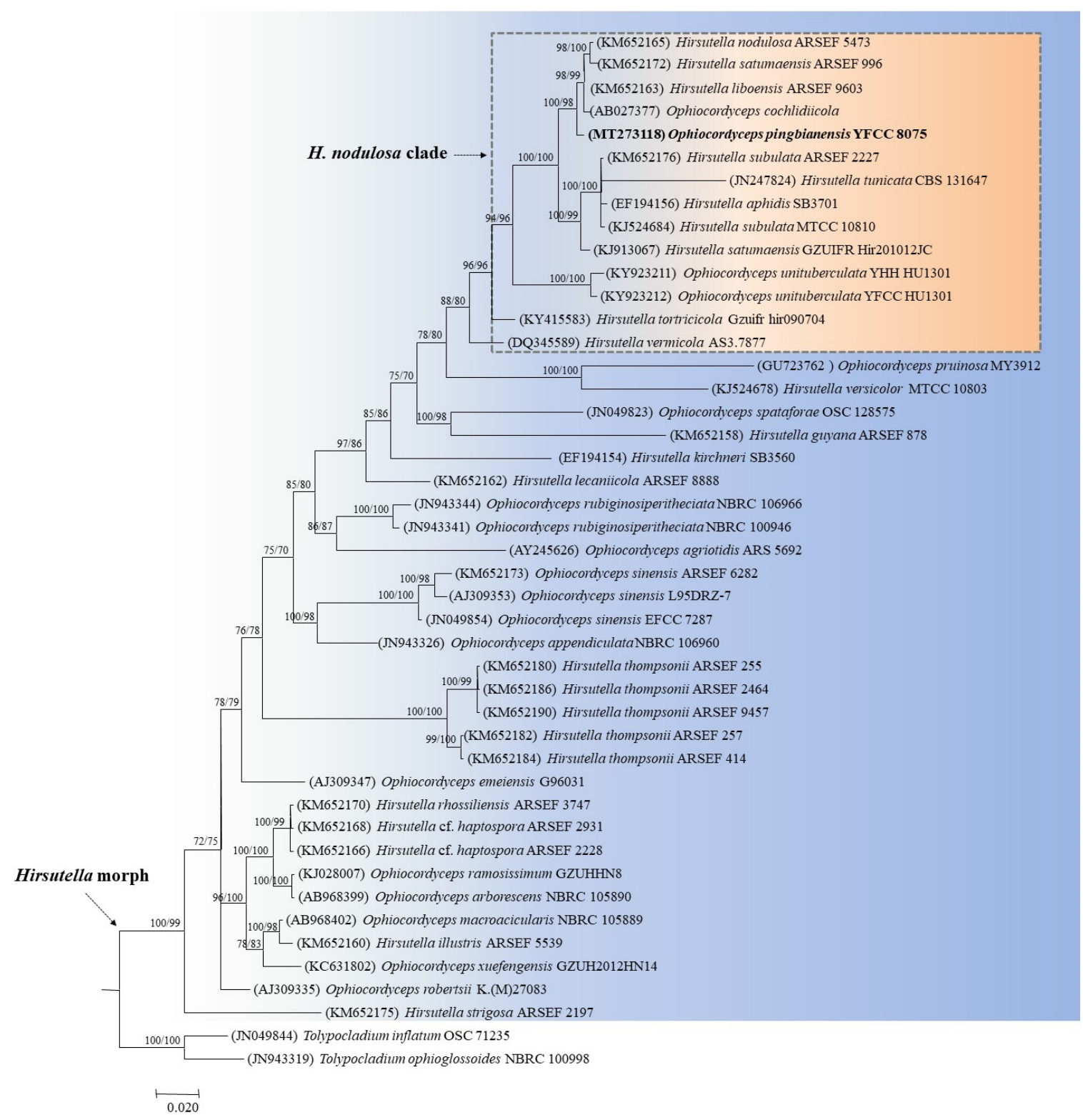

Figure 2. Phylogenetic relationships of Ophiocordyceps pingbianensis to the related taxa from ML and BI analyses based on ITS sequences. Values at the nodes before and after the backslash are ML bootstrap proportions and BI posterior probabilities, respectively. Support values greater than $50 \%$ are indicated at the nodes. Phylogenetic tree shows that $O$. pingbianensis belongs to the $H$. nodulosa clade in the genus Ophiocordyceps with Hirsutella morph. Tolypocladium inflatum and T. ophioglossoides were designed as the outgroup. GenBank accession numbers for ITS sequences are placed in the bracket before the taxon name.

\subsection{Phylogenetic Analysis Based on Mitochondrial Genes}

The ML tree and BI tree were estimated for the mitochondrial PCG dataset of 52 species in Ascomycota from GenBank (Table S2). The six well-supported clades of Hypocreales were recognized by ML and BI analyses, including species of the families Bionectriaceae, Clavicipitaceae, Cordycipitaceae, Hypocreaceae, Nectriaceae and Ophiocordycipitaceae (Figure 3). As indicated from the phylogenetic analysis, the new species was a member of the family Ophiocordycipitaceae. The new species was clustered together with $H$. minnesotensis and H. vermicola in the genus Ophiocordyceps of Ophiocordycipitaceae. 


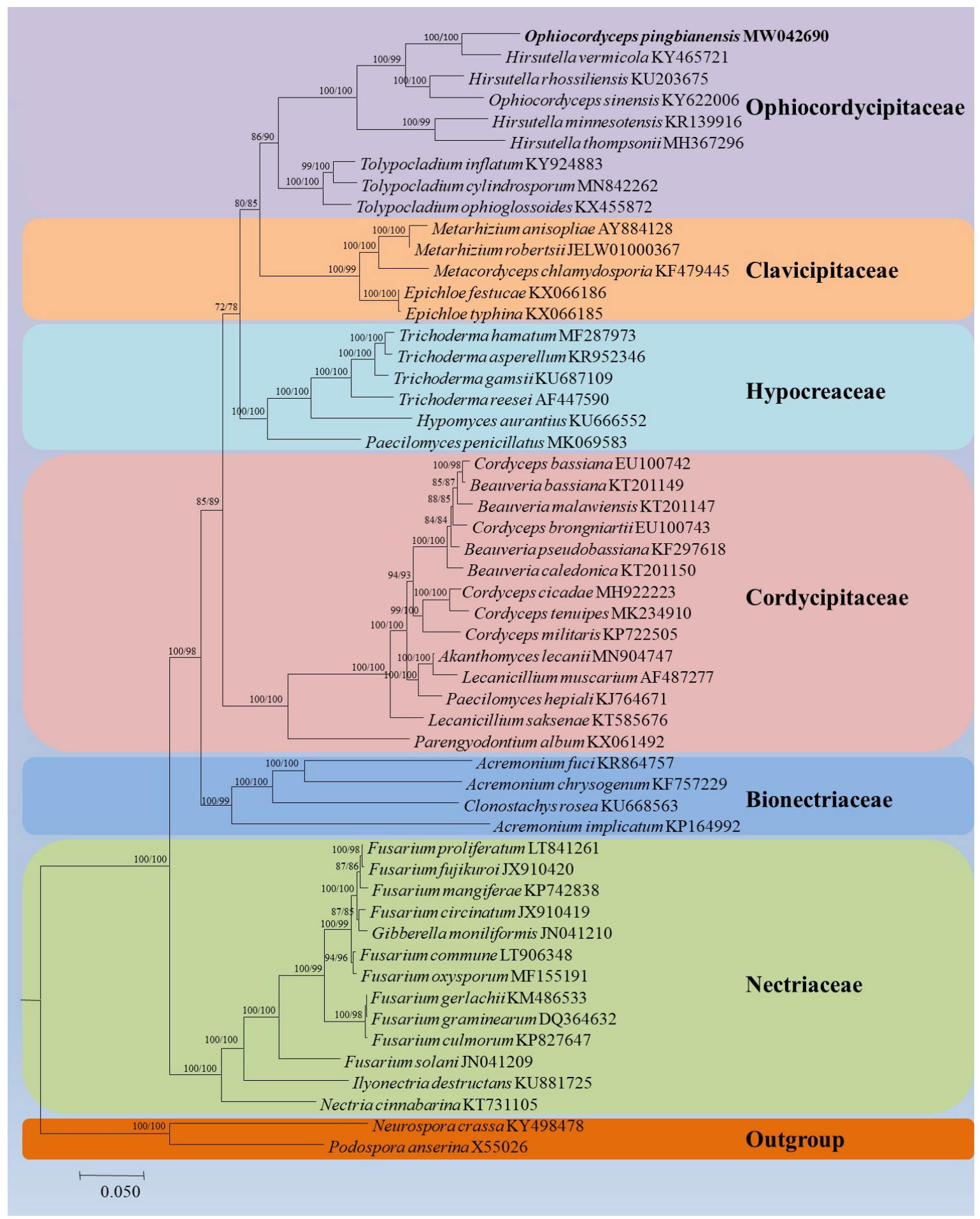

Figure 3. Phylogenetic relationships among 53 taxa of Sordariomycetes based on ML and BI analyses from 14 concatenated mitochondrial protein-coding genes (PCGs). The 14 PCGs included subunits of the respiratory chain complexes (cob, cox1, cox2, cox3), ATPase subunits (atp6, atp8, atp9), NADH: quinone reductase subunits (nad1, nad2, nad3, nad4, nad4L, nad5, nad6). Values at the nodes before and after the backslash are ML bootstrap proportions and BI posterior probabilities, respectively. Support values greater than $50 \%$ are indicated at the nodes. Phylogenetic tree shows the placement of O. pingbianensis in the family Ophiocordycipitaceae. Neurospora crassa and Podospora anserina were designed as the outgroup.

\subsection{Taxonomy}

Ophiocordyceps pingbianensis H. Yu, S.Q. Chen and Y.B. Wang, sp. nov. (Figure 4) 


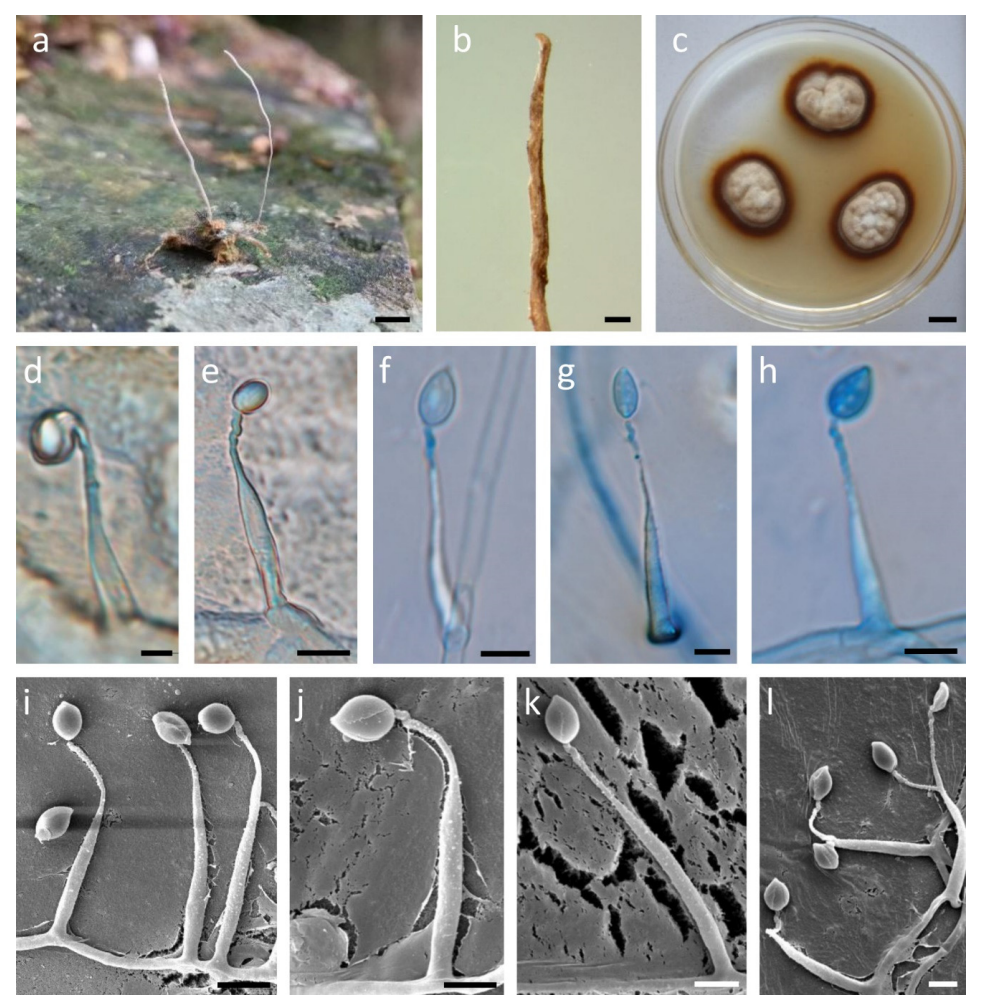

Figure 4. Ecology and morphology of Ophiocordyceps pingbianensis. (a) Stromata arising from a Larva of tiger beetle of Coleoptera; (b) The tip of a stroma; (c) Colony on PDA medium; (d-1) Conidiogenous cells. Scale bars: $(\mathbf{a})=0.5 \mathrm{~cm} ;(\mathbf{b})=500 \mu \mathrm{m} ;(\mathbf{c})=1 \mathrm{~cm} ;(\mathbf{d}-\mathbf{l})=5 \mu \mathrm{m}$.

MycoBank: MB 840055.

Etymology: Named after the location Pingbian County where this species was collected.

Holotype: China. Yunnan Province: Pingbian County, Daweishan National Nature Reserve, at $103^{\circ} 41^{\prime} 57^{\prime \prime} \mathrm{E}, 22^{\circ} 57^{\prime} 45^{\prime \prime} \mathrm{N}$, alt. $1536 \mathrm{~m}$, on a tiger beetle of Coleoptera buried in the moss in a cave, 17 June 2019, Y.B. Wang (YHH 18766, holotype; YFCC 8075, ex-holotype living culture).

Stromata geminate, slender, smooth and unbranched, flexible to ligneous, with surface color from light deep yellow to dark brown, $17-21(\overline{\mathrm{x}}=19) \mathrm{mm}$ in length, 0.16-0.21 $(\overline{\mathrm{x}}=0.19)$ $\mathrm{mm}$ in width. Colonies on PDA slow-growing, with a diam up to $18-20 \mathrm{~mm}$ after 4 weeks at $4{ }^{\circ} \mathrm{C}$, lanate, consisting of a loose mycelial felt with annulation, beige to pale brown, dark brown at the edge. After $90 \mathrm{~d}$ of culture, stromata were not observed. Hyphae hyaline, septate, branched, smooth-walled, $2.8-4.4 \mu \mathrm{m}(\overline{\mathrm{x}}=3.6)$ in width. Conidiogenous cells monophialidic, non-septate, arising from hyphae laterally, with an inflated awl-shaped base, 20.4-31.6 $\mu \mathrm{m}(\bar{x}=26.0)$ long, 3.2 $-5.2 \mu \mathrm{m}(\bar{x}=4.2)$ wide at the base, phialide neck twisty and warty, $0.6-1.4 \mu \mathrm{m}(\overline{\mathrm{x}}=1.0)$ wide at the apex. Conidia solitary, hyaline, aseptate, smooth-walled, fusiform or oval, 3.1-5.3 $\times 4.6-7.5 \mu \mathrm{m}(\overline{\mathrm{x}}=3.9 \times 6.4)$, embedded in a mucous sheath of $6.5-8.6 \times 7.1-9.2 \mu \mathrm{m}(\overline{\mathrm{x}}=6.8 \times 8.9)$.

Host: Larva of a tiger beetle (Coleoptera).

Habitat: Buried in the moss in a cave.

Type locality: Daweishan National Nature Reserve, Pingbian County, Yunnan Province, China.

Sexual stage: The fruiting body was not observed.

Notes: Ophiocordyceps pingbianensis is characterized by geminate stromata, slender, unbranched and a surface color from light deep yellow to dark brown; monophialidic conidiogenous cells with an inflated awl-shaped base, twisty and warty phialide neck, fusiform or oval conidia. Morphological comparison showed that O. pingbianensis was distinct from other closely related species (Table 1), which was concordant with molecular phylogenetic results. 
Table 1. A morphological comparison of Ophiocordyceps pingbianensis and its related species.

\begin{tabular}{|c|c|c|c|c|c|c|}
\hline Species & Host & Habitat & Synnemata/Stromata & Conidiogenous Cells & Conidia & References \\
\hline H. aphidis & Aphids & On plant & Small or as short cushions & $\begin{array}{l}\text { Narrowly conical, length }(17-90 \mu \mathrm{m}) \text {, neck } \\
\text { width }(0.6-1.0 \mu \mathrm{m}) \text {, base width }(2.6-4.0 \mu \mathrm{m})\end{array}$ & $\begin{array}{l}\text { Slightly crescent-shaped or } \\
\text { cymbiform, usually in pairs, } \\
7.0-18.3 \times 2.8-4.6 \mu \mathrm{m} \text {, with } \\
\text { mucous sheath }\end{array}$ & [42] \\
\hline H. liboensis & $\begin{array}{l}\text { Larvae of Cossidae } \\
\quad \text { (Lepidoptera) }\end{array}$ & In tree hole & Clustered & $\begin{array}{c}\text { Base significantly swollen, length }(28-30 \mu \mathrm{m}) \text {, } \\
\text { neck width }(1-2 \mu \mathrm{m}), \text { twisting in } 2-3 \text { helices at } \\
\text { the apex, base width }(3-4.5 \mu \mathrm{m})\end{array}$ & $\begin{array}{l}\text { Fusiform or orange-segmented, } \\
\text { in pairs or single, } 6-8 \times 3-5 \mu \mathrm{m}, \\
\text { with mucous sheath }\end{array}$ & [43] \\
\hline H. nodulosa & Lepidoptera, Acari & On plant & None & $\begin{array}{l}\text { Base swollen, length }(20-35 \mu \mathrm{m}) \text {, base width } \\
(4 \mu \mathrm{m}) \text {, neck often twists in a helix at the apex, } \\
\text { neck width }(1 \mu \mathrm{m}) \text {, with tiny warts }\end{array}$ & $\begin{array}{l}\text { Ellipsoid or like orange } \\
\text { segments, } 5-6 \times 3 \mu \mathrm{m} \text {, with } \\
\text { mucous sheath }\end{array}$ & [44] \\
\hline O. pingbianensis & $\begin{array}{l}\text { Larvae of tiger beetle } \\
\quad \text { (Coleoptera) }\end{array}$ & Clinging to fallen leaves & $\begin{array}{l}\text { Geminate, } \\
17-21 \times 0.16-0.21\end{array}$ & $\begin{array}{c}\text { Base obviously swollen, length }(20.4-31.6 \mu \mathrm{m}) \text {, } \\
\text { base width }(3.2-5.2 \mu \mathrm{m}), \text { neck width } \\
(1-1.5 \mu \mathrm{m}), \text { twisty and warty at the apex }\end{array}$ & $\begin{array}{l}\text { Solitary, fusiform or oval, } \\
5.3-7.5 \mu \mathrm{m} \text { long, } 3.14 .6 \mu \mathrm{m} \text { wide, } \\
\text { with mucous sheath }\end{array}$ & This study \\
\hline H. satumaensis & $\begin{array}{l}\text { Larvae of Bombyx mori } \\
\quad \text { (Lepidoptera) }\end{array}$ & On plant & $\begin{array}{l}\text { Clustered, } \\
3.0-6.5 \times 0.5 \mathrm{~mm}\end{array}$ & $\begin{array}{l}\text { With conoid to cylindrical base, size }(5-17 \times \\
3-4.5 \mu \mathrm{m}) \text {, neck length }(7 \mu \mathrm{m}) \text {, twisting in a } \\
\text { helix at the apex; base with warts }\end{array}$ & $\begin{array}{l}\text { Fusiform or like orange } \\
\text { segments, } 5-7.5 \times 3-5 \mu \mathrm{m} \text {, with } \\
\text { mucous sheath }\end{array}$ & {$[14,45]$} \\
\hline H. subuluta & Larvae of Lepidoptera & On plant & $\begin{array}{c}\text { Solitary, } \\
15-50 \times 0.1-0.3 \mathrm{~mm}\end{array}$ & $\begin{array}{l}\text { Phialidic, neck 6-12 } \mu \mathrm{m} \text { long, base size }(4-8 \times \\
\qquad 3-5 \mu \mathrm{m})\end{array}$ & $\begin{array}{l}\text { Narrowly ellipsoid, in pairs or } \\
\text { single, } 4-8 \times 1.5-2.5 \mu \mathrm{m} \text {, with } \\
\text { mucous sheath. }\end{array}$ & [16] \\
\hline H. tortricicola & $\begin{array}{l}\text { Larvae of Tortricidae } \\
\quad \text { (Lepidoptera) }\end{array}$ & In wilted leaf & Solitary & $\begin{array}{l}\text { Base obviously swollen, length }(18-22 \mu \mathrm{m}) \text {, } \\
\text { base width }(3.5-4 \mu \mathrm{m}) \text {, neck width }(1-1.5 \mu \mathrm{m}) \text {, } \\
\text { neck often twists in } 1-2 \text { helices at the apex }\end{array}$ & $\begin{array}{c}\text { Ellipsoid or like orange } \\
\text { segments, in pairs or single, } \\
2.7-3.6 \times 1.4-1.8 \mu \mathrm{m} \text {, with } \\
\text { mucous sheath }\end{array}$ & [46] \\
\hline O. unituberculata & $\begin{array}{l}\text { Larvae of Noctuidae } \\
\quad \text { (Lepidoptera) }\end{array}$ & $\begin{array}{l}\text { In soil or cling to the fallen } \\
\text { leaves }\end{array}$ & $\begin{array}{c}\text { Clustered, } \\
5-76 \times 0.4-0.7 \mathrm{~mm}\end{array}$ & $\begin{array}{c}\text { With an inflated awl-shaped base, length } \\
(31.9-128.3 \mu \mathrm{m}) \text {, base width }(1.8-5.0 \mu \mathrm{m}) \text {, neck } \\
\text { width }(0.5-1.2 \mu \mathrm{m}) \text {. With a large periclinal } \\
\text { protuberance near the apex }\end{array}$ & $\begin{array}{l}\text { Solitary, lanceolate to fusiform, } \\
6.3-10.6 \times 1.9-3.7 \mu \mathrm{m} \text {, with } \\
\text { mucous sheath }\end{array}$ & [18] \\
\hline H. vermicola & $\begin{array}{l}\text { Bacteria-feeding } \\
\text { nematodes }\end{array}$ & In soil & None & $\begin{array}{l}\text { Base obviously swollen, length }(14-26 \mu \mathrm{m}) \text {, } \\
\text { base width }(3.0-5.0 \mu \mathrm{m}) \text {, neck width }(1-2 \mu \mathrm{m}) \text {, } \\
\text { neck often twists in a helix towards the apex }\end{array}$ & $\begin{array}{l}\text { More or less ellipsoid, single or } \\
\text { in groups of } 2-8 \times 3-5 \mu \mathrm{m} \text {, with } \\
\text { mucous sheath }\end{array}$ & [47] \\
\hline
\end{tabular}




\subsection{Mitogenomic Characteristics of Ophiocordyceps Pingbianensis}

The complete mitogenome of $O$. pingbianensis was an obvious circular molecule with a length of $80,359 \mathrm{bp}$ (Figure 5). It had an overall GC content of $29.89 \%$. The mitogenome of $O$. pingbianensis was a rather high capacity and compacted genome with genic regions (including intronic regions) accounting for $71.54 \%$ and intergenic regions taking up $27 \%$. The protein-coding regions took up $92.19 \%$ of the whole mitogenome of O. pingbianensis, containing 2 rRNA genes (i.e., $r n l$ and $r n s$ ) genes, 15 standard protein-coding genes (PCGs), 24 ORFs, 25 transfer genes (tRNAs) (Table S3). The sizes of $r n s$ and $r n l$ were $1652 \mathrm{bp}$ and $6444 \mathrm{bp}$, respectively. The total length of the 15 PCGs was $14682 \mathrm{bp}$, including 3 subunits of cytochrome c oxidase (cox1, cox2 and cox3), 3 subunits of ATP synthase (atp6, atp 8 and atp9), one cytochrome b gene ( $\mathrm{cob}$ ) and seven subunits of NADH dehydrogenase complex (nad1, nad2, nad3, nad4, nad5, nad6 and nad4L) and 1 ribosomal protein S3 (rps3). The lengths of 25 tRNAs ranged from 69 to 84 bp and 24 ORFs (orf 146, orf 132, orf293, orf 276, orf 306, orf 412, orf 371, orf 508, orf 310, orf 473, orf341, orf394_2, orf332, orf 105, orf 114, orf623, orf 394, orf 164, orf $108, \operatorname{orf} 374$, orf $358, \operatorname{orf} 302, \operatorname{orf} 757$ and orf 268$).$

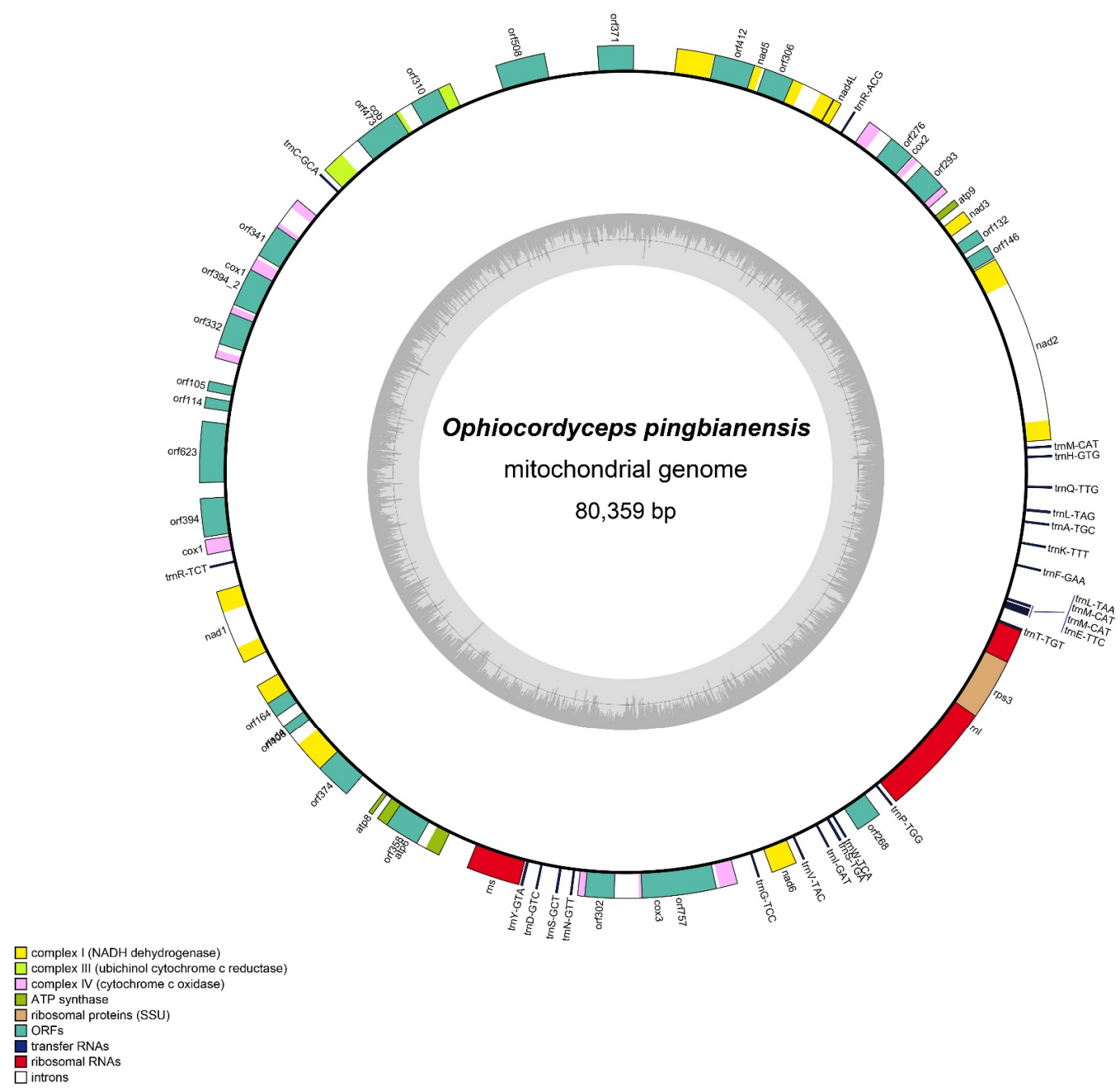

Figure 5. The mitogenomic circular map of the complete mitochondrial genome of Ophiocordyceps pingbianensis. Genes are represented with different color blocks.

\subsection{Codon Usage}

The codon usage of mitochondrial genes (atp6-9, cob, cox1-3, nad1-6, nad $4 \mathrm{~L}$, orf 146 , $\operatorname{orf} 132, \operatorname{orf} 293, \operatorname{orf} 276, \operatorname{orf} 306, \operatorname{orf} 412, \operatorname{orf} 371, \operatorname{orf} 508, \operatorname{orf} 310, \operatorname{orf} 473, \operatorname{orf} 341, \operatorname{orf} 3942, \operatorname{orf} 332$, $\operatorname{orf} 105, \operatorname{orf} 114, \operatorname{orf} 623, \operatorname{orf} 394, \operatorname{orf} 164, \operatorname{orf} 108, \operatorname{orf} 374, \operatorname{orf} 358, \operatorname{orf} 302, \operatorname{orf} 757$ and $\operatorname{orf} 268)$ of 
O. pingbianensis was determined. The frequency of initiation codon ATG was the highest, followed by AAA, orf 473, orf394_2, orf332 and orf302 started with "AAA", orf 146, orf 293 and $\operatorname{orf} 341$ started with "AGA", orf 164 and orf 358 started with "AAC". The frequency of stop codon TAA was the highest, followed by TAG. Only cox1 was terminated by "GCT" (Table S4). Leucine was the most common amino acid in the PCGs in the mitogenome of O. pingbianensis, followed by Arginine (Table S5). For codon usage, the most commonly used codons were UUA (3.88\%), AGA (3.6\%), CCU (2.37\%), GCU (1.99\%), UCU (1.94\%), and GGU $(1.93 \%)$, and the least used codons included CUG $(0.19 \%)$, AUC $(0.18 \%)$, ACC $(0.17 \%)$, CGG $(0.15 \%)$ and CUC $(0.11 \%)$.

\subsection{Transfer RNAs}

In the mitogenome of $O$. pingbianensis, the 25 tRNAs coded for all 20 amino acids (Table S6). As indicated from the results, all tRNAs adopt a typical cloverleaf structure except for $t r n \mathrm{~S}-\mathrm{GCT}$, $\operatorname{trn} \mathrm{Y}-\mathrm{GTA}, \operatorname{trn} \mathrm{L}-\mathrm{TAA}, \operatorname{trn} \mathrm{L}-\mathrm{TAG}$ and $t r n \mathrm{~S}$-TGA (Figure 6). As shown in Table S6, some of the 25 tRNAs existed in multiple copies, the trnM-CAT gene for methionine appeared in three copies. Two different tRNAs for arginine (trnR-ACG and trnRTCT), Serine (trnS-GCT and $t r n S-T G A)$ and Leucine ( $t r n \mathrm{~L}-\mathrm{TAA}$ and $t r n \mathrm{~L}-\mathrm{TAG}$ ) were found.
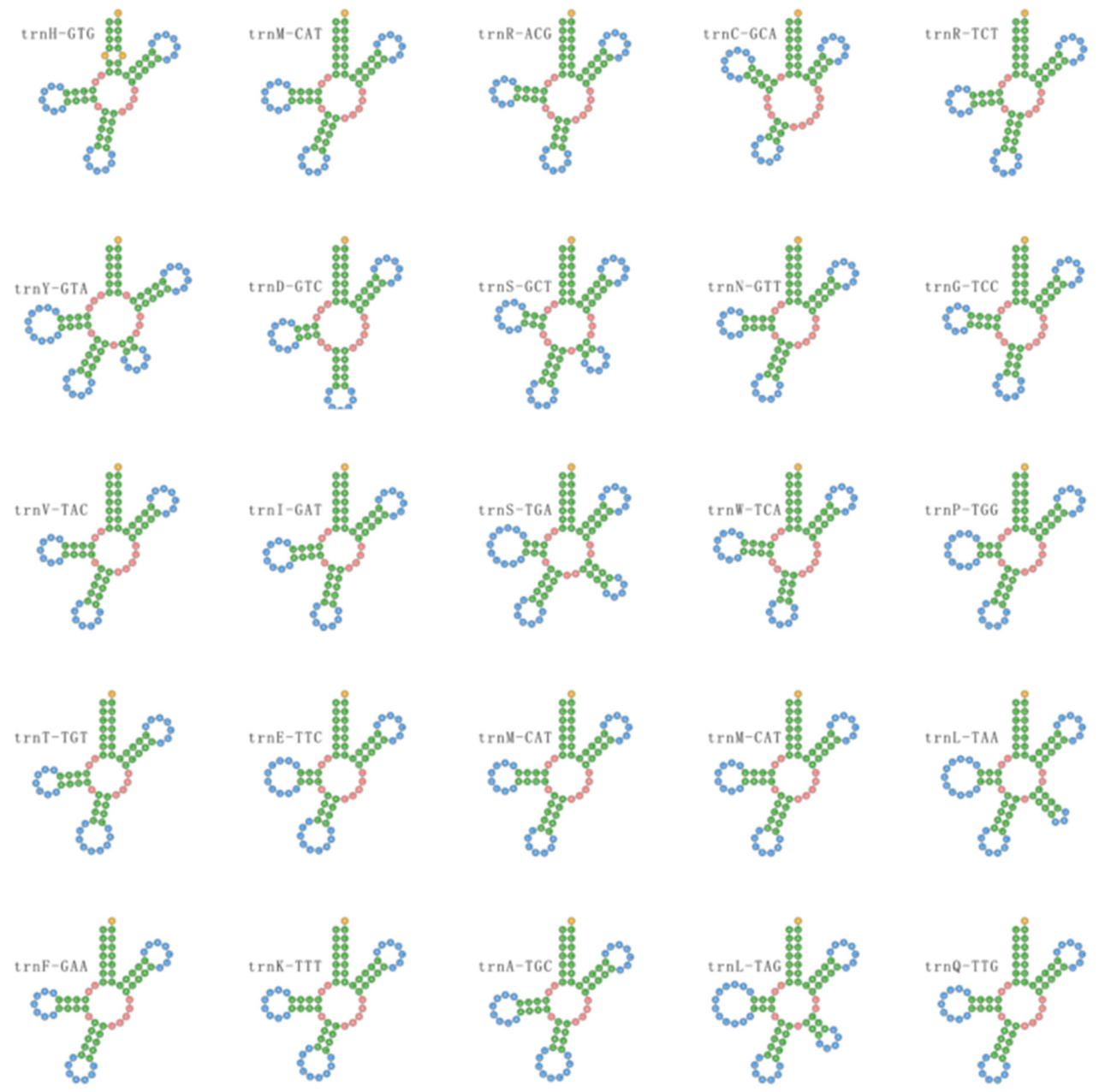

Figure 6. The predicted tRNA structures of Ophiocordyceps pingbianensis. Secondary structures predicted by tRNA scan-SE show that all tRNAs adopt a typical cloverleaf structure except for trnS-GCT, trn Y-GTA, trnL-TAA, trnL-TAG and trnS-TGA.

\subsection{Gene Arrangement Analysis}

Overall, the lative positions of most PCGs and tRNAs were relatively conservative across the six Ophiocordyceps species (Figure 7). However, several tRNAs and PCGs were 
distributed in different positions in six mitogenomes, showing the variability of the relative gene order of these mitogenomes. As revealed from the results of genomic synteny (Figure 8), the six Ophiocordyceps mitogenomes fell to $4-5$ homologous regions. Homologous regions were identified in the mitogenome of O. pingbianensis and H. minnesotensis, adding the homologous region $\mathrm{B}$. However, there was an absence of the homologous region $\mathrm{B}$ in mitogenomes of $O$. sinensis, $H$. thompsonii, $H$. vermicola and $H$. rhossiliensis. The relevant orders of four homologous regions A, C, D and E were conserved across the six Ophiocordyceps mitogenomes. The homologous regions B was distributed in different positions of all the mitogenomes.

\begin{tabular}{|c|c|c|c|c|c|}
\hline O. pingbianensis & H. minnesotensis & H. rhossiliensis & H. thompsonii & H. vermicola & O. sinensis \\
\hline $\mathrm{rnl}$ & $\mathrm{rnl}$ & $\mathrm{rnl}$ & $\mathrm{rnl}$ & $\mathrm{rnl}$ & $\mathrm{rnl}$ \\
\hline trnT-TGT & грs3 & $\operatorname{trnT}$-TGT & trnT-TGT & $\operatorname{trnT}$-TGT & грs3 \\
\hline trnE-TTC & trnT-TGT & trnE-TTC & trnE-TTC & trnE-TTC & trnT-TGT \\
\hline trnM-CAT & $\operatorname{tmE}$-TTC & tmM-CAT & trnM-CAT & tmM-CAT & trnG-TTC \\
\hline trnM-CAT & trnM-CAT & tmM-CAT & trnM-CAT & tmM-CAT & $\operatorname{trnM}-\mathrm{CAT}$ \\
\hline trnL-TAA & trnM-CAT & $\operatorname{trnF}-G A A$ & $\operatorname{trnL}-\mathrm{GAA}$ & trnL-GAA & trnM-CAT \\
\hline $\operatorname{trnF}-\mathrm{GAA}$ & trnL-TAA & trnL-TAA & $\operatorname{trn} \mathrm{A}-\mathrm{TGC}$ & $\operatorname{trnF}-\mathrm{GAA}$ & $\operatorname{trnL}-\mathrm{TAA}$ \\
\hline trnK-TTT & $\operatorname{trn} \mathrm{A}-\mathrm{TGC}$ & $\operatorname{trnF}-\mathrm{GAA}$ & $\operatorname{trnF}-\mathrm{GAA}$ & trnK-TTT & trnP-GAA \\
\hline $\operatorname{trn} \mathrm{A}-\mathrm{TGC}$ & $\operatorname{trnF}-\mathrm{GAA}$ & trnK-TTT & $\operatorname{trnK}$-TTT & $\operatorname{trn} \mathrm{A}-\mathrm{TGC}$ & trnL-TTT \\
\hline $\operatorname{trnL-TAG}$ & $\operatorname{trnK}-\mathrm{TTT}$ & $\operatorname{trn} A-T G C$ & trnL-TAG & trnL-TAG & $\operatorname{trn} \mathrm{A}-\mathrm{TGC}$ \\
\hline trnQ-TTG & trnL-TAG & $\operatorname{trnL}-\mathrm{TAG}$ & trnQ-TTG & $\operatorname{trnQ}-\mathrm{TTG}$ & $\operatorname{trnG}-\mathrm{TCC}$ \\
\hline $\operatorname{trnH}$-GTG & $\operatorname{trnQ}$-TTG & $\operatorname{trnQ}$-TTG & trnH-GTG & $\operatorname{trnH-GTG}$ & trnL-TAG \\
\hline trnM-CAT & trnH-GTG & trnH-GTG & trnM-CAT & trnM-CAT & trnG-TTG \\
\hline nad2 & trnM-CAT & tmM-CAT & nad2 & nad2 & trnH-GTG \\
\hline $\operatorname{nad} 3$ & nad2 & nad2 & nad3 & nad3 & trnM-CAT \\
\hline atp9 & nad3 & nad3 & atp9 & atp9 & nad2 \\
\hline $\cos 2$ & atp9 & atp9 & $\cos 2$ & $\cos 2$ & nad3 \\
\hline $\operatorname{trnR}-\mathrm{ACG}$ & $\cos 2$ & $\cos 2$ & $\operatorname{trn} R-A C G$ & $\operatorname{trnR}-\mathrm{ACG}$ & atp9 \\
\hline $\operatorname{nad} 4 \mathrm{~L}$ & $\operatorname{trnR}-\mathrm{ACG}$ & $\operatorname{trnR}-A C G$ & $\operatorname{nad} 4 \mathrm{~L}$ & $\operatorname{nad} 4 \mathrm{~L}$ & $\cos 2$ \\
\hline nad5 & $\operatorname{nad} 4 \mathrm{~L}$ & $\operatorname{nad} 4 \mathrm{~L}$ & nad5 & nad5 & $\operatorname{trn} \mathrm{A}-\mathrm{ACG}$ \\
\hline cob & $\operatorname{nad} 5$ & nad5 & cob & cob & $\operatorname{nad} 4 \mathrm{~L}$ \\
\hline $\operatorname{trnC}-\mathrm{GCA}$ & cob & cob & $\operatorname{trnC}-\mathrm{GCA}$ & $\operatorname{trnC}-\mathrm{GCA}$ & nad5 \\
\hline $\operatorname{cox} 1$ & $\operatorname{trnC}-\mathrm{GCA}$ & $\operatorname{trnC}-\mathrm{GCA}$ & $\operatorname{cox} 1$ & $\operatorname{cox} 1$ & cob \\
\hline trnR-TCT & $\operatorname{cox} 1$ & $\operatorname{cox} 1$ & $\operatorname{trnR-TCT}$ & trnR-TCT & $\operatorname{trnC}-\mathrm{GCA}$ \\
\hline nad 1 & trnR-TCT & trnR-TCT & $\operatorname{trnC}-\mathrm{GCA}$ & nad1 & $\operatorname{cox} 1$ \\
\hline $\operatorname{nad} 4$ & nad1 & nad1 & nad1 & nad4 & $\operatorname{trn} \mathrm{A}-\mathrm{TCT}$ \\
\hline atp8 & nad4 & $\operatorname{nad} 4$ & nad4 & atp8 & nad1 \\
\hline atp6 & atp8 & atp8 & atp8 & atp6 & nad4 \\
\hline rns & atp6 & atp6 & atp6 & rns & atp8 \\
\hline $\operatorname{trnY-GTA}$ & rns & rns & rns & $\operatorname{trnY-GTA}$ & atp6 \\
\hline $\operatorname{trnD-GTC}$ & $\operatorname{trnY-GTA}$ & $\operatorname{trnY}$-GTA & $\operatorname{trnY-GTA}$ & $\operatorname{trnD-GTC}$ & rns \\
\hline trnS-GCT & $\operatorname{trnD-GTC}$ & $\operatorname{trnD-GTC}$ & $\operatorname{trnD-GTC}$ & trnS-GCT & trnT-GTA \\
\hline trnN-GTT & trnS-GCT & trnS-GCT & trnS-GCT & $\operatorname{trnN-GTT}$ & $\operatorname{trn} \mathrm{A}-\mathrm{GTC}$ \\
\hline $\cos 3$ & tmN-GTT & trnN-GTT & $\operatorname{tmn}$-GTT & $\cos 3$ & tmS-GCT \\
\hline trnG-TCC & $\cos 3$ & $\cos 3$ & $\cos 3$ & $\operatorname{trnG-TCC}$ & trnA-GTT \\
\hline nad6 & $\operatorname{trnG-TCC}$ & $\operatorname{trnG-TCC}$ & trnG-ACC & nad6 & $\cos 3$ \\
\hline $\operatorname{trnV}-\mathrm{TAC}$ & nad6 & nad6 & trnG-TCC & $\operatorname{trnV}-\mathrm{TAC}$ & trnI-TAT \\
\hline trnI-GAT & $\operatorname{trnV-TAC}$ & $\operatorname{trnV-TAC}$ & nad6 & trnI-GAT & $\operatorname{trnG-TCC}$ \\
\hline trnS-TGA & trnI-GAT & $\operatorname{trnI}-\mathrm{GAT}$ & $\operatorname{trnV}$-TAC & trnS-TGA & nad6 \\
\hline trnW-TCA & trnS-TGA & trnS-TGA & trnI-GAT & trnW-TCA & $\operatorname{trnV-TAC}$ \\
\hline trnP-TGG & trnW-TCA & trnW-TAC & trnS-TGA & trnP-TGG & trnI-GAT \\
\hline \multirow[t]{3}{*}{ rps3 } & tmP-TGG & trnP-TGG & $\operatorname{tmW}$-TCA & & trnS-TGA \\
\hline & & & trnP-TGG & & $\operatorname{trnT}$-TCA \\
\hline & & & & & trnP-TGG \\
\hline
\end{tabular}

Figure 7. A comparison of gene order among six Ophiocordyceps mitogenomes. The genes are colored on the basis of their functional groups. The non-coding region (NCR) is not indicated. 


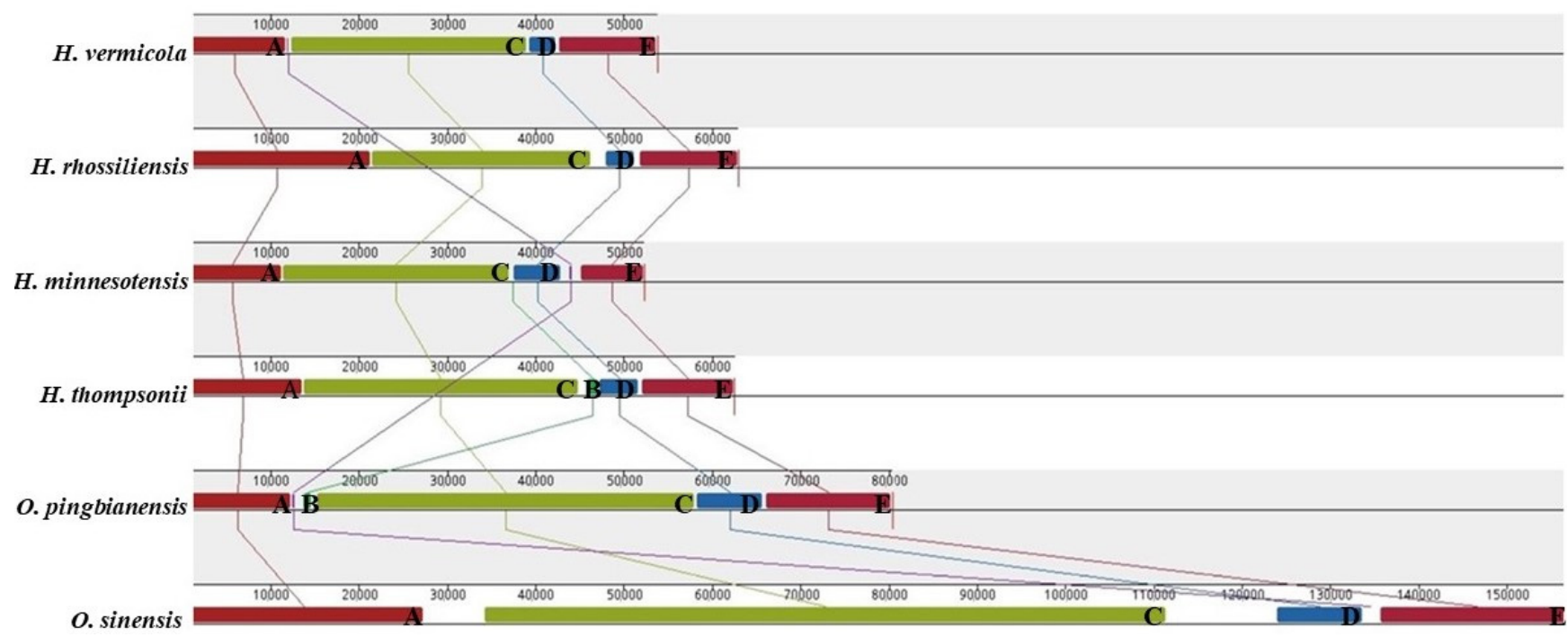

Figure 8. Mitogenome collinearity analysis of six Ophiocordyceps species. The progressive Mauve alignment shows the homologous regions shared among the mitogenomes, and it also connected these regions with lines, indicating their corresponding positions among the homologous regions in order to visualize the gene arrangement. (A-E) represent different homologous regions.

\section{Discussion}

By morphological and molecular phylogenetic researches, O. pingbianensis was found as a novel species, being belonged to the H. nodulosa clade. Morphological differences still exist between $O$. pingbianensis and its related species, such as the conidiogenous cells of $H$. liboensis with being smooth and polyphialidic [43]. O. pingbianensis has a warty phialide neck of conidiogenous cells, whereas a larger periclinal protuberance was produced near the apex of conidiogenous cells of O. unituberculata H. Yu, Y.B. Wang and Y.D. Dai [18]. Conidia of O. pingbianensis were smooth, fusiform or oval, inconsistent with $O$. unituberculata with larger lanceolate to fusiform conidia and $H$. nodulosa with non-mucoid conidia. The host of $O$. pingbianensis was a tiger beetle of Coleoptera; however, these hosts of its closely related species $H$. satumaensis, $H$. nodulosa, $H$. liboensis and O. cochlidiicola are Lepidoptera.

The mitogenome of $O$. pingbianensis was a circular DNA molecule with a length of $80,359 \mathrm{bp}$, and the mitogenome size was the second largest within the mitogenomes of the Ophiocordycipitaceae species reported. The mitogenome sizes were different among species in Ophiocordyceps attributed to differences in the number of introns. For instance, the H. thompsonii mitogenome exhibited 15 introns [25], the H. rhossiliensis mitogenome had 13 introns [48], the H. minnesotensis mitogenome had 13 introns [24] and the H. vermicola mitogenome exhibited 7 introns [47]. The mitogenome size of $O$. pingbianensis was the second largest because it contained 27 introns. The mitochondrial genome of $\mathrm{H}$. minnesotensis exhibited significant intron degeneration for the nad4L and cox1-i1 genes, which might be caused by unexpected stop codons or frame shifting [24]. In H. rhossiliensis, there were 10 group I introns and one unclassified intron in six genes (i.e., $r n l, \operatorname{cob}, \operatorname{cox} 1, \operatorname{cox} 3$, nad 1 and nad5) [48]. This indicated an intron presence/absence dynamics cause mitogenome size variations in the Ophiocordyceps species. On the whole, 27 ORFs were identified in O. pingbianensis, and except for orf 144 , orf 131 , all ORFs were transcribed at the identical orientation. In the mitogenomes of five Ophiocordyceps species reported, the number of ORFs was also different, e.g., the H. thompsonii mitogenome containing 3 ORFs [25], H. rhossiliensis mitogenome containing 5 ORFs [48], H. minnesotensis mitogenome containing 4 ORFs [24], as well as the H. vermicola mitogenome containing 3 ORFs [47]. 
To gain more insights into the variability of the mitochondrial gene among Ophiocordyceps species, the genomic arrangements of $O$. pingbianensis with other five mitogenomes in Ophiocordyceps were analyzed comparatively. The lative positions of most PCGs and most tRNAs of the six Ophiocordyceps species were relatively conservative, except for several tRNAs and PCGs distributed in different positions, which resulted from the variability of the relative gene order of these mitogenomes.

As revealed from genomic synteny, the six Ophiocordycep mitogenomes falled to $4-5$ homologous regions. Homologous region B only existed in the mitogenome of $O$. pingbianensis and $H$. minnesotensis, however, it was lacked in $H$. thompsonii, $H$. vermicola, $H$. rhossiliensis and $O$. sinensis mitogenomes. The relevant orders of four homologous regions (i.e., A, $\mathrm{C}, \mathrm{D}$ and E)were conserved across the six Ophiocordyceps mitogenomes and homologous regions $\mathrm{B}$ were distributed in different positions among the mitogenomes; as a result, the diversity of gene order was generated among six mitogenomes. Gaining insights into gene arrangements, component and genomic synteny of Ophiocordyceps species might help assemble mitogenomes and trace the evolutionary history of other Ophiocordycipitaceae species in future research.

Supplementary Materials: The following are available online at https:/ /www.mdpi.com/article/ 10.3390/life11070686/s1, Table S1: Specimen information and GenBank accession numbers for sequences used in this study. Table S2: Specimen information and GenBank accession numbers for mitogenomes used in this study. Table S3: General features in the mitogenome of Ophiocordyceps pingbianensis. Table S4: Gene component of the mitogenome from Ophiocordyceps pingbianensis. Table S5: Codon usage of protein-coding genes in the mitogenome from Ophiocordyceps pingbianensis. Table S6: tRNAs in the mitogenome from Ophiocordyceps pingbianensis.

Author Contributions: Y.W. collected the specimen; H.Y., Y.W. and S.C. designed the experiments; S.C. and Y.W. conducted the experiments; S.C., Y.W. and K.Z. performed studies of morphology mitogenomics and phylogeny; S.C. and Y.W. wrote the manuscript and H.Y. edited the manuscript. All authors have read and agreed to the published version of the manuscript.

Funding: This research was funded by the National Natural Science Foundation of China [31870017, 31760011], and the Department of Science and Technology of Yunnan Province [2018FY001(-006), 2018IA075].

Institutional Review Board Statement: Not applicable.

Informed Consent Statement: Not applicable.

Data Availability Statement: Not applicable.

Acknowledgments: The authors wish to thank Qi Fan and Zhihong Xu for isolating and depositing strains of $O$. puluongensis.

Conflicts of Interest: The authors declare no conflict of interest.

\section{References}

1. Sung, G.H.; Hywel-Jones, N.L.; Sung, J.M.; Luangsa-Ard, J.J.; Shrestha, B.; Spatafora, J.W. Phylogenetic classification of Cordyceps and the clavicipitaceous fungi. Stud. Mycol. 2007, 57, 5-59. [CrossRef]

2. Petch, T. Notes on entomogenous fungi. Trans. Brit. Mycol. Soc. 1931, 16, 55-75. [CrossRef]

3. Shrestha, B.; Zhang, W.M.; Zhang, Y.J.; Liu, X.Z. What is the Chinese caterpillar fungus Ophiocordyceps sinensis (Ophiocordycipitaceae)? Mycology 2010, 1, 228-236. [CrossRef]

4. Kobayasi, Y. The genus Cordyceps and its allies. Science reports of the Tokyo Bunrika Daigaku. Sci. Rep. Tokyo Bun. Daigaku 1941, 5, 53-260.

5. Kobayasi, Y. Keys to the taxa of the genera Cordyceps and Torrubiella. Trans. Mycol. Soc. Jpn. 1982, 23, 329-364.

6. Mains, E.B. North American entomogenous species of Cordyceps. Mycologia 1958, 50, 169-222. [CrossRef]

7. Sanjuan, T.I.; Fanco-Molano, A.E.; Kepler, R.M.; Spatafora, J.W.; Tabima, J.; Vasco-palacios, A.M.; Restrepo, S. Five new species of entomopathogenic fungi from the Amazon and evolution of neotropical Ophiocordyceps. Fungal Biol. 2015, 119, 901-916. [CrossRef]

8. Spatafora, J.W.; Quandt, C.A.; Kepler, R.M.; Sung, G.H.; Shrestha, B.; Hywel-Jones, N.L.; Luangsa-ard, J.J. New 1F1N species combinations in Ophiocordycipitaceae (Hypocreales). IMA Fungus 2015, 6, 357-362. [CrossRef] 
9. Araújo, J.P.M.; Evans, H.C.; Kepler, R.M.; Hughes, D.P. Zombie-ant fungi across continents: 15 new species and new combinations within Ophiocordyceps. I. Myrmecophilous hirsutelloid species. Stud. Mycol. 2018, 90, 119-160. [CrossRef]

10. Khonsanit, A.; Luangsa-ard, J.J.; Thanakitpipattana, D.; Kobmoo, N.; Piasai1, O. Cryptic species within Ophiocordyceps myrmecophila complex on formicine ants from Thailand. Mycol. Prog. 2018, 18, 147-161. [CrossRef]

11. Luangsa-ard, J.J.; Tasanathai, K.; Thanakitpipattana, D.; Khonsanit, A.; Stadler, M. Novel and interesting Ophiocordyceps spp (Ophiocordycipitaceae, Hypocreales) with superficial perithecia from Thailand. Stud. Mycol. 2018, 89, 125-142. [CrossRef] [PubMed]

12. Wijayawardene, N.N.; Hyde, K.D.; Lumbsch, H.T.; Liu, J.K.; Maharachchikumbura, S.S.; Ekanayaka, A.H.; Tian, Q.; Phookamsak, R. Outline of Ascomycota 2017. Fungal Divers. 2018, 88, 167-263. [CrossRef]

13. Tasanathai, K.; Noisripoom, W.; Chaitika, T.; Khonsanit, A.; Hasin, S.; Luangsa-Ard, J.J. Phylogenetic and morphological classification of Ophiocordyceps species on termites from Thailand. MycoKeys 2019, 56, 101-129. [CrossRef] [PubMed]

14. Quandt, C.A.; Kepler, R.M.; Gams, W.; Araújo, J.P.; Ban, S.; Evans, H.C.; Luangsa-Ard, J.J. Phylogenetic-based nomenclatural proposals for Ophiocordycipitaceae (Hypocreales) with new combinations in Tolypocladium. IMA Fungus 2014, 5, 121-134. [CrossRef]

15. Ban, S.; Sakane, T.; Nakagiri, A. Three new species of Ophiocordyceps and overview of anamorph types in the genus and the family Ophiocordyceptaceae. Mycol. Prog. 2015, 14, 1017. [CrossRef]

16. Hodge, K.T. Revisionary Studies in Hirsutella (Anamorphic Hyphomycetes: Clavicipitaceae). Ph.D. Thesis, Cornell University, New York, NY, USA, 1998.

17. Simmons, D.R.; Kepler, R.M.; Rehner, S.A.; Groden, E. Phylogeny of Hirsutella species (Ophiocordycipitaceae) from the USA: Remedying the paucity of Hirsutella sequence data. IMA Fungus 2015, 6, 345-356. [CrossRef]

18. Wang, Y.B.; Nguyen, T.T.; Dai, Y.D.; Yu, H.; Wu, C.K. Molecular phylogeny and morphology of Ophiocordyceps unituberculata sp. nov. (Ophiocordycipitaceae), a pathogen of caterpillars (Noctuidae, Lepidoptera) from Yunnan, China. Mycol. Prog. 2018, 17, 745-753. [CrossRef]

19. Williams, S.T.; Foster, P.G.; Littlewood, D.T. The complete mitochondrial genome of a turbinid vetigastropod from MiSeq Illumina sequencing of genomic DNA and steps towards a resolved gastropod phylogeny. Gene 2014, 533, 38-47. [CrossRef]

20. Botero-Castro, F.; Tilak, M.K.; Justy, F.; Catzeflis, F.; Delsuc, F.; Douzery, E.J. Next generation sequencing and phylogenetic signal of complete mitochondrial genomes for resolving the evolutionary history of leaf-nosed bats (Phyllostomidae). Mol. Phylogenet. Evol. 2013, 69, 728-739. [CrossRef]

21. James, T.Y.; Pelin, A.; Bonen, L.; Ahrendt, S.; Sain, D.; Corradi, N.; Stajich, J.E. Shared signatures of parasitism and phylogenomics unite the Cryptomycota and Microsporidia. Curr. Biol. 2013, 23, 1548-1553. [CrossRef]

22. Liu, W.; Cai, Y.L.; Zhang, Q.Q.; Chen, L.F.; Shu, F.; Ma, X.L.; Bian, Y.B. The mitochondrial genome of Morchella importuna (272.2 kb) is the largest among fungi and contains numerous introns, mitochondrial non-conserved open reading frames and repetitive sequences. Int. J. Biol. Macromol. 2019, 143, 373-381. [CrossRef]

23. Kang, X.; Hu, L.; Shen, P.; Li, R.; Liu, D. SMRT sequencing revealed mitogenome characteristics and mitogenome-wide DNA modification pattern in Ophiocordyceps sinensis. Front. Microbiol. 2017, 8, 1422. [CrossRef]

24. Zhang, Y.J.; Zhang, S.; Liu, X. The complete mitochondrial genome of the nematode endoparasitic fungus Hirsutella minnesotensis. Mitochondrial DNA Part A 2016, 27, 2693-2694. [CrossRef] [PubMed]

25. Zhang, Y.J.; Wang, L.; Zhang, S.; Li, J.H. Mitochondrial genome, comparative analysis and evolutionary insights into the entomopathogenic fungus Hirsutella thompsonii. Environ. Microbiol. 2018, 20, 3393-3405. [CrossRef]

26. Wang, Y.B.; Wang, Y.; Fan, Q.; Duan, D.E.; Zhang, G.D.; Dai, R.Q.; Dai, Y.D.; Zeng, W.B.; Chen, Z.H.; Li, D.D.; et al. Multigene phylogeny of the family Cordycipitaceae (Hypocreales): New taxa and the new systematic position of the Chinese cordycipitoid fungus Paecilomyces hepiali. Fungal Divers. 2020, 103, 1-46. [CrossRef]

27. Liu, X.Z.; Chen, S.Y. Screening isolates of Hirsutella species for biocontrol of Heterodera glycines. Biocontrol. Sci. Tech. 2001, 11, 151-160. [CrossRef]

28. Wang, Y.B.; Yu, H.; Dai, Y.D.; Wu, C.K.; Zeng, W.B.; Yuan, F.; Liang, Z.Q. Polycephalomyces agaricus, a new hyperparasite of Ophiocordyceps sp. infecting melolonthid larvae in southwestern China. Mycol. Prog. 2015, 14, 70. [CrossRef]

29. Vilgalys, R.; Hester, M. Rapid genetic identification and mapping of enzymatically amplified ribosomal DNA from several Cryptococcus species. J. Bacteriol. 1990, 172, 4238-4246. [CrossRef]

30. Rehner, S.A.; Samuels, G.J. Taxonomy and phylogeny of Gliocladium analysed from nuclear large subunit ribosomal DNA sequences. Mycol. Res. 1994, 98, 625-634. [CrossRef]

31. Bischoff, J.F.; Rehner, S.A.; Humber, R.A. Metarhizium frigidum sp. nov.: A cryptic species of M. anisopliae and a member of the M. flavoviride Complex. Mycologia 2006, 98, 737-745. [CrossRef]

32. White, T.J.; Bruns, T.D.; Lee, S.B.; Taylor, J.W. Amplification and direct sequencing of fungal ribosomal RNA genes for phylogenetics. In Pcr Protocols: A Guide to Methods and Applications; Innis, M.A., Gelfand, D.H., Sninsky, J.J., White, T.J., Eds.; Academic Press: New York, NY, USA, 1990; pp. 315-322.

33. Wang, Y.B.; Yu, H.; Dai, Y.D.; Chen, Z.H.; Zeng, W.B.; Yuan, F.; Liang, Z.Q. Polycephalomyces yunnanensis (Hypocreales), a new species of Polycephalomyces parasitizing Ophiocordyceps nutans and stink bugs (hemipteran adults). Phytotaxa 2015, $208,34-44$. [CrossRef] 
34. Bankevich, A.; Nurk, S.; Antipov, D.; Gurevich, A.A.; Dvorkin, M.; Kulikov, A.S.; Lesin, V.M.; Nikolenko, S.L.; Pham, S.; Prjibelski, A.D.; et al. SPAdes: A new genome assembly algorithm and its applications to single-cell sequencing. J. Comput. Biol. 2012, 19, 455-477. [CrossRef]

35. Valach, M.; Burger, G.; Gray, M.W.; Lang, B.F. Widespread occurrence of organelle genome-encoded 5S rRNAs including permuted molecules. Nucleic Acids Res. 2014, 42, 13764-13777. [CrossRef]

36. Lohse, M.; Drechsel, O.; Bock, R. Organellargenomedraw (ogdraw): A tool for the easy generation of high-quality custom graphical maps of plastid and mitochondrial genomes. Curr. Genet. 2007, 52, 267-274. [CrossRef]

37. Larkin, M.A.; Blackshields, G.; Brown, N.P.; Chenna, R.; McGettigan, P.A.; McWilliam, H.; Valentin, F.; Wallace, I.M.; Wilm, A.; Lopez, R.; et al. Clustal W and Clustal X version 2.0. Bioinformatics 2007, 23, 2947-2948. [CrossRef]

38. Tamura, K.; Stecher, G.; Peterson, D.; Filipski, A.; Kumar, S. MEGA6: Molecular Evolutionary Genetics Analysis Version 6.0. Mol. Biol. Evol. 2013, 30, 2725-2729. [CrossRef]

39. Edgar, R.C. MUSCLE: Multiple sequence alignment with high accuracy and high throughput. Nucleic Acids Res. 2004, 32, 1792-1797. [CrossRef]

40. Stamatakis, A. RAxML-VI-HPC: Maximum likelihood-based phylogenetic analyses with thousands of taxa and mixed models. Bioinformatics 2006, 22, 2688-2690. [CrossRef] [PubMed]

41. Ronquist, F.; Huelsenbeck, J.P. MrBayes 3: Bayesian phylogenetic inference under mixed models. Bioinformatics. 2003, 19, 1572-1574. [CrossRef]

42. Brady, S. Notes on Hirsutella aphidis. Trans. Br. Mycol. Soc. 1985, 85, 752-756. [CrossRef]

43. Zou, X.; Liu, A.Y.; Liang, Z.Q.; Han, Y.N.; Yang, M.F. Hirsutella liboensis, a new entomopathogenic species affecting Cossidae (Lepidoptera) in China. Mycotaxon 2010, 111, 34-44. [CrossRef]

44. Minter, D.W.; Brady, B.L. Mononematous species of Hirsytella. Trans. Br. Mycol. Soc. 1980, 74, 271-282. [CrossRef]

45. Aoki, K.; Nakasato, Y.; Fujimoto, I.; Suzuki, K. Studies on the new fungous parasites of silkworms, Bombyx Mori L. IV. Hirsutella satumaensis Aoki sp. nov. Bull. Seric. Exp. Stn. 1957, 14, 471-486.

46. Zou, X.; Zhou, Y.M.; Liang, Z.Q.; Xu, F.L. A new species of the genus Hirsutella with helical twist neck of phialides parasitized on Tortricidae. Mycosystema 2016, 53, 807-813.

47. Xiang, M.C.; Yang, E.C.; Xiao, Q.M.; Liu, X.Z.; Chen, S.Y. Hirsutella vermicola sp. nov., a new species parasitizing bacteria-feeding nematodes. Fungal Divers. 2006, 19, 217-234. [CrossRef]

48. Wang, N.N.; Zhang, Y.J.; Hussain, M.; Li, K.; Xiang, M.H.; Liu, X.Z. The mitochondrial genome of the nematode endoparasitic fungus Hirsutella rhossiliensis. Mitochondrial DNA Part B 2016, 27, 2693-2694. [CrossRef] 